\title{
Sources, size distribution, and downwind grounding of aerosols from Mount Etna
}

\author{
A. G. Allen, ${ }^{1}$ T. A. Mather, ${ }^{2}$ A. J. S. McGonigle, ${ }^{3}$ A. Aiuppa ${ }^{4}$ P. Delmelle, ${ }^{5}$ B. Davison, ${ }^{6}$ \\ N. Bobrowski, ${ }^{7}$ C. Oppenheimer, ${ }^{8}$ D. M. Pyle, ${ }^{2}$ and S. Inguaggiato ${ }^{9}$ \\ Received 24 March 2005; revised 6 December 2005; accepted 25 January 2006; published 23 May 2006.
}

[1] The number concentrations and size distributions of aerosol particles $>0.3 \mu \mathrm{m}$ diameter were measured at the summit of Mount Etna and up to $10 \mathrm{~km}$ downwind from the degassing vents during July and August 2004. Aerosol number concentrations reached in excess of $9 \times 10^{6} \mathrm{~L}^{-1}$ at summit vents, compared to $4-8 \times 10^{4} \mathrm{~L}^{-1}$ in background air. Number concentrations of intermediate size particles were higher in emissions from the Northeast crater compared to other summit crater vents, and chemical composition measurements showed that Northeast crater aerosols contained a higher mineral cation content compared to those from Voragine or Bocca Nuova, attributed to Strombolian or gas puffing activity within the vent. Downwind from the summit the airborne plume was located using zenith sky ultraviolet spectroscopy. Simultaneous measurements indicated a coincidence of elevated ground level aerosol concentrations with overhead $\mathrm{SO}_{2}$, demonstrating rapid downward mixing of the plume onto the lower flanks of the volcano under certain meteorological conditions. At downwind sites the ground level particle number concentrations were elevated in all size fractions, notably in the $2.0-7.5 \mu \mathrm{m}$ size range. These findings are relevant for assessing human health hazard and suggest that aerosol size distribution measurements may aid volcanic risk management.

Citation: Allen, A. G., T. A. Mather, A. J. S. McGonigle, A. Aiuppa, P. Delmelle, B. Davison, N. Bobrowski, C. Oppenheimer, D. M. Pyle, and S. Inguaggiato (2006), Sources, size distribution, and downwind grounding of aerosols from Mount Etna, J. Geophys. Res., 111, D10302, doi:10.1029/2005JD006015.

\section{Introduction}

[2] Observation of the chemical and physical properties of volcanic plumes is used to track ongoing volcanic eruptions, examine the mechanism of eruptive processes, estimate fluxes to the atmosphere of volcanogenic materials, predict environmental impacts, and to measure the changes in activity levels which can precede large eruptive events [e.g., Oppenheimer et al., 2003]. Techniques traditionally used for these purposes include remote sensing measurements such as ultraviolet spectroscopy (COSPEC or Ocean

\footnotetext{
${ }^{1}$ School of Geography, Earth and Environmental Sciences, University of Birmingham, Birmingham, UK.

${ }^{2}$ Department of Earth Sciences, University of Cambridge, Cambridge, $\mathrm{UK}$.

${ }^{3}$ Department of Geography, University of Sheffield, Sheffield, UK.

${ }^{4}$ Dipartimento di Chimica e Fisica della Terra ed Applicazioni, University of Palermo, Palermo, Italy.

${ }^{5}$ Environmental Health Unit, Institut Scientifique de Service Public, Liège, Belgium.

${ }^{6}$ Institute of Environmental and Natural Sciences, University of Lancaster, Lancaster, UK.

${ }^{7}$ Institute of Environmental Physics, University of Heidelberg, Heidelberg, Germany.

${ }_{9}^{8}$ Department of Geography, University of Cambridge, Cambridge, UK.

${ }^{9}$ Istituto Nazionale di Geofisica e Vulcanologia, Palermo, Italy.

Copyright 2006 by the American Geophysical Union. 0148-0227/06/2005JD006015
}

Optics USB2000 instruments) [Stoiber et al., 1983; Platt, 1999; Galle et al., 2003], or Fourier transform infrared spectroscopy [Mori et al., 1993; Francis et al., 1998; Love et al., 1998; Horrocks et al., 1999; Allard et al., 2005]. Satellite systems have also made important contributions to volcanic monitoring [Bluth et al., 1993; Carn et al., 2003], and recently electrochemical sensors have been used for the direct measurement of volcanic gases [Shinohara, 2005]. Here, we explore the potential of a ground-based in situ portable aerosol spectrometer to detect and characterize volcanic plumes at up to several kilometers downwind of degassing vents. Measurements were made at active vents as well as downwind, where the aerosol instrument was colocated with a miniature UV spectrometer measuring the atmospheric $\mathrm{SO}_{2}$ column.

[3] Mount Etna, a 3300-m-high stratovolcano, has been active for at least $200 \mathrm{kyr}$ [Chester et al., 1985]. Its eruptive style is characterized by short periods of effusive and explosive eruptions interspersed by longer periods of quiescent (open-conduit) degassing [e.g., Tanguy et al., 1997; Bonaccorso et al., 2004], making the volcano, at times, Europe's largest point source of $\mathrm{SO}_{2}, \mathrm{HCl}$ and $\mathrm{HF}$ gases [Allard, 1997; Francis et al., 1998; Caltabiano et al., 2004]. Recent large flank eruptions occurred during 2001 and 2002-2003 [Aiuppa et al., 2002; Andronico et al., 2003, 2005]. After the end of the 2002-2003 eruption on 28 January 2003 activity has taken the form of continued quiescent degassing from the four active summit craters 


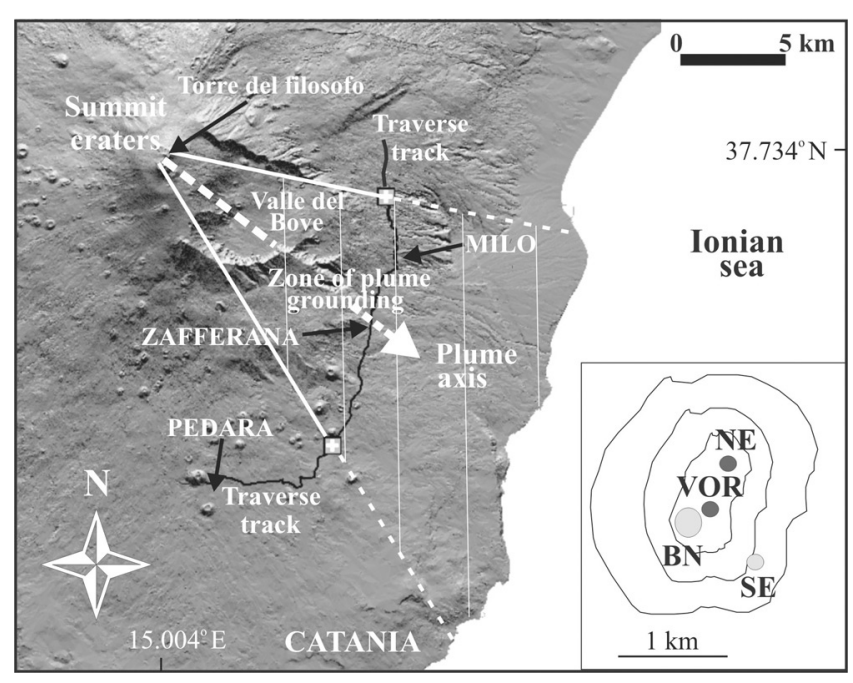

Figure 1. Map showing Mount Etna, direction of the plume on 4 August 2004, and route taken during traverses. Inset shows a sketch contour map of the summit region (contours at $3000 \mathrm{~m}, 3100 \mathrm{~m}$ and $3200 \mathrm{~m}$ ) and the location of summit craters: NE, Northeast; VOR, Voragine; BN, Bocca Nuova; and SE, Southeast (modified after Behncke and Neri [2003]).

(Bocca Nuova, Voragine, Southeast and Northeast) at 3200-3300 m a.s.1., with a new effusion event on Etna's eastern flank starting on 7 September 2004 and ending around 8 March 2005 [Andronico, 2005; Burton et al., 2005]. During noneruptive degassing fumigation of extensive areas on the eastern flanks has been associated with elevated concentrations of acidic volcanogenic volatiles [Aiuppa et al., 2004], showing that emissions from the summit vents can readily reach lower altitudes. Observations at Etna witness that the transport behavior of the plume from the summit craters is governed by the meteorological conditions, of which wind speed is probably the most important factor (another is the height of the near-surface mixing layer). For light winds or nearstagnant conditions we have observed the plume to flow away from the summit with negligible downward mixing, however at higher wind speeds there is increasing tendency for the plume to be entrained following the contours of the volcano and descending along the flanks. For example lofting of the plume during the early morning may be followed, with increasing wind speed, by fumigation of the flanks by late morning. During the period of this study (summer 2004) the volcanic plume was advected to the southeast, frequently funneling down the Valle del Bove and over populated areas including the towns of Milo and Zafferana, before being transported over the Ionian Sea (Figure 1).

\section{Methods}

[4] Measurements were made at Etna's summit craters and on the upper flank near Torre del Filosofo on 28 July, 2-3 August and 21-24 August 2004. Measurements in the Valle del Bove were made on 22 August. An instrumented four-wheel drive vehicle was used to conduct four traverses of the Etna plume on the southeastern flank of the volcano, ca. $10 \mathrm{~km}$ downwind, between 0700-1500 UT on 4 August 2004. The traverse route is shown in Figure 1.

\subsection{Aerosol Number Concentration}

[5] Aerosol number concentrations were measured using Grimm Aerosol Technik GmbH (Ainring, Germany) Aerosol Spectrometers (Model 1.108). In this instrument ambient air is pumped (at $1.2 \mathrm{~L} \mathrm{~min}^{-1}$ ) through a detector cell containing a semiconductor laser light source, generating a scattered light signal proportional to the size of the aerosol particle causing the light scatter. A receptor diode collects the $90^{\circ}$ scattered light, the signal being processed in a multichannel size classifier. The optics are protected against contamination using a sheath air flow, and all particles are collected on a downstream filter for gravimetric or chemical analysis (if required). A total of 15 size bins are available $(0.3-0.4,0.4-0.5,0.5-0.65$, $0.65-0.8,0.8-1.0,1.0-1.6,1.6-2.0,2.0-3.0,3.0-4.0$, $4.0-5.0,5.0-7.5,7.5-10.0,10.0-15.0,15.0-20.0,>20 \mu \mathrm{m}$ diameter). The instrument is field portable, weighing $2.4 \mathrm{~kg}$, with maximum operational period of up to 7 hours using an integral internal battery (or indefinite with an external 110/220V supply). Data were collected continuously as $1 \mathrm{~min}$ averages, stored on a removable data card, and downloaded and processed using Grimm 1.174 software. Ambient temperature and humidity were measured continuously using a Grimm Model 1.154 accessory sensor probe, with data also stored as $1 \mathrm{~min}$ averages. The aerosol spectrometer was deployed on foot at the summit, and downwind was positioned on the roof of a 4WD vehicle, with a short $(30 \mathrm{~cm})$ inlet tube extension (fabricated from $6 \mathrm{~mm}$ outer diameter copper tubing) positioned facing forward. This arrangement avoided any possibility of contamination from the vehicle's exhaust while in forward motion.

\subsection{Aerosol Mass and Composition}

[6] Coarse $(>3.5 \mu \mathrm{m})$ and fine $(<3.5 \mu \mathrm{m})$ particles were collected by sequential filtration onto $47 \mathrm{~mm}$ diameter Nuclepore and PTFE membrane filters, respectively [Allen et al., 2002a, 2004]. Following sample collection filters were placed in several layers of small sealable polyethylene bags and refrigerated. The mass of collected material was determined by weighing the filters before and after exposure using a Sartorius Model MC5 microbalance with readability of $1 \mu \mathrm{g}$ [Yin et al., 2005]. Filters were conditioned for 24 hours prior to weighing at a relative humidity of $35-$ $45 \%$ and a temperature of $20 \pm 2{ }^{\circ} \mathrm{C}$, in a chamber supplied with ammonia-free air (to avoid any neutralization of the acidity of the collected aerosol), and an antistatic blower and an $\alpha$-particle source $\left(\mathrm{Po}^{210}\right)$ were used during weighing to eliminate interference from static electricity. Subsequently filter sections were extracted into distilled, deionized, water under mechanical agitation for $30 \mathrm{~min}$. Anions (fluoride, chloride, nitrate and sulfate) were analyzed using a Dionex DX500 ion chromatograph fitted with an AS4A-SC analytical column, gradient pump, automated $\mathrm{KOH}$ eluent generator and self-regenerating suppressor. Calibration was external with construction of calibration curves from known concentrations of aqueous standards. Cations (sodium, am- 


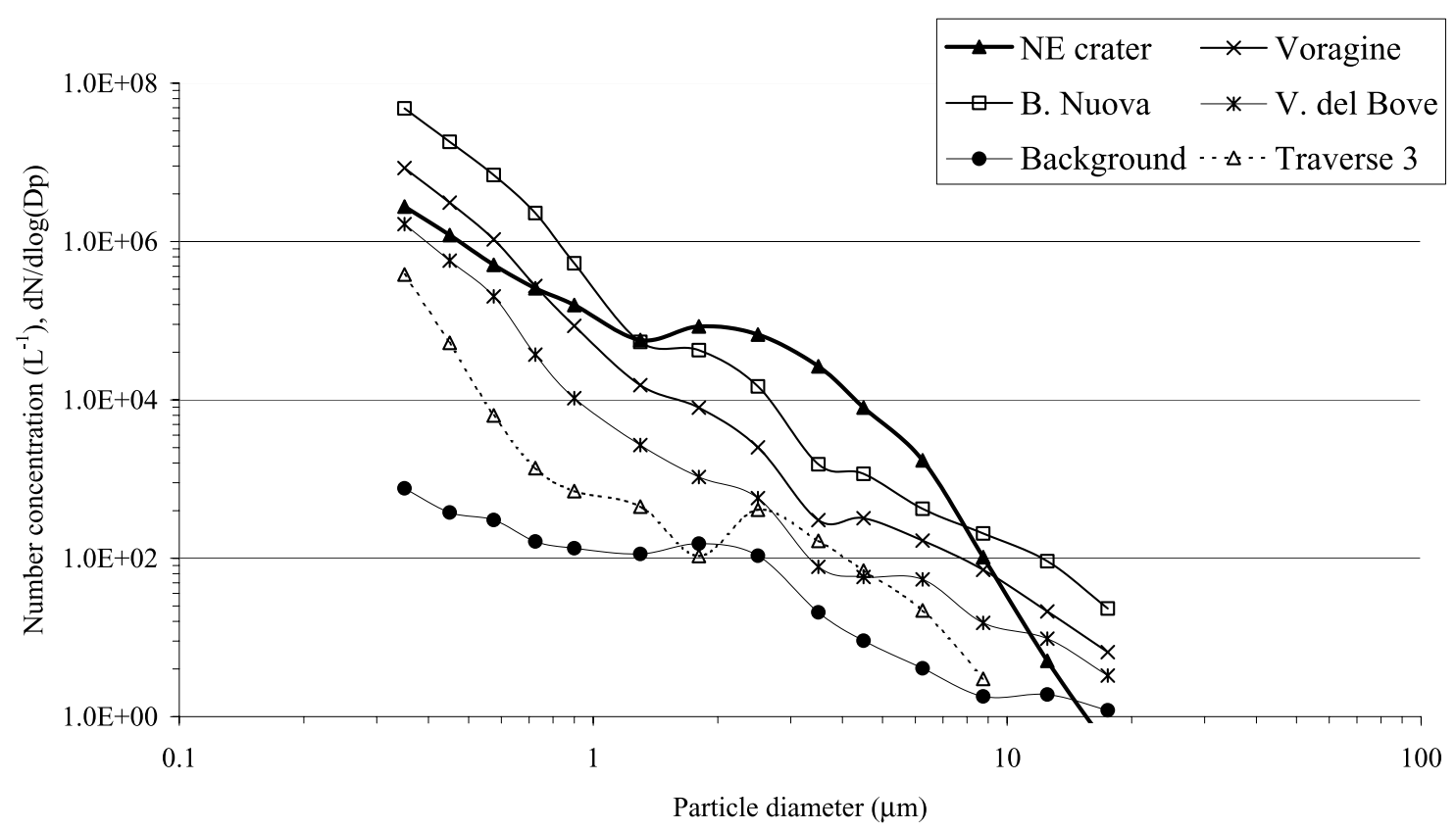

Figure 2. Mean aerosol size distributions at Northeast crater $(n=131)$, Voragine $(n=263)$, Bocca Nuova $(n=10)$, in the mixed plume flowing down the Valle del Bove $(n=49)$, in upwind background air $(n=31)$ and at the time of the peak aerosol concentration measured downwind during traverse T3 $(n=1)$.

monium, potassium, magnesium and calcium) were determined using a Dionex DX100 ion chromatograph fitted with a CS12A analytical column, isocratic pump, selfregenerating suppressor and employing $30 \mathrm{mN}$ sulfuric acid as eluent. Hydrogen ion content of the extracts was determined using an Orion 701 A pH meter fitted with a Russell glass combination electrode, accurate to $0.01 \mathrm{pH}$ units and calibrated using buffer solutions at $\mathrm{pH} 4$ and 7. Full details of these analytical procedures have been published previously [Mather et al., 2003].

\section{3. $\mathrm{SO}_{2}$ Column}

[7] During downwind traverses around Etna's flanks, overhead $\mathrm{SO}_{2}$ concentration measurements were made with an Ocean Optics Inc. USB2000 spectrometer, of 245$400 \mathrm{~nm}$ spectral range and $0.5 \mathrm{~nm}$ resolution. Light was coupled into the USB2000s $50 \times 1000 \mu \mathrm{m}$ entrance slit from the linear end of an antisolarant circular-to-linear converter optical fiber bundle $(4 \times 200 \mu \mathrm{m})$ of $2 \mathrm{~m}$ length. The other bundle end was attached to a telescope, of $\approx 7 \mathrm{mrad}$ quasi-circular field of view, consisting of two plano-convex antireflection coated focusing lenses ( $\mathrm{f}=$ $250 \mathrm{~mm}, \phi=25 \mathrm{~mm}$ and $F=27 \mathrm{~mm}, \phi=9 \mathrm{~mm}$, separated by $\approx 160 \mathrm{~mm}$ ). The spectrometer was connected to a laptop PC with a USB cable, which powered the USB2000 and enabled computer-instrument communication. Data capture, and analysis and instrumental control were achieved using JScripts executed with DOASIS (University of Heidelberg) software. During measurements, spectra were acquired with a time step of $\approx 2.5 \mathrm{~s}$, by averaging $10-20$ spectra of $120-$ $250 \mathrm{~ms}$ integration times, depending on available skylight intensity. The spectra were evaluated in real time, using a differential optical absorption spectroscopy routine, as described elsewhere [e.g., Galle et al., 2003]. The telescope was clamped to one of the vehicle's windows and arranged to point vertically.

\section{Results and Discussion}

3.1. Aerosol Number Size Distribution and Chemistry

[8] During the measurements transparent and condensing plumes were emitted from Bocca Nuova, Voragine and Northeast craters, typically with volcanic cloud formation a short distance downwind (1-2 km) before cloud evaporation to leave a semitransparent haze. Initial aerosol measurements in the separate plumes from Voragine and Bocca Nuova showed that while higher number concentrations were measured at Bocca Nuova, the size distributions from these two vents were near identical (Figure 2), so that all subsequent measurements were made at a more convenient summit location in the mixed plume from these two craters. Frequent discoloration of the Northeast crater plume was suggestive of higher ash content relative to emissions from the other summit sources, as also supported by audible Strombolian or gas puffing activity at depth in the crater. This was reflected in the composition of aerosol samples collected using pumped filters at the active vents, which showed distinct differences in the chemistry between emissions from the Northeast crater vent, and those from Voragine or Bocca Nuova vents, which were similar (Table 1). On average, the sum of the masses of the major soluble ionic species $\left(\mathrm{F}^{-}, \mathrm{Cl}^{-}, \mathrm{SO}_{4}^{2-}, \mathrm{NO}_{3}^{-}, \mathrm{Na}^{+}, \mathrm{NH}_{4}^{+}, \mathrm{K}^{+}\right.$, $\mathrm{Mg}^{2+}, \mathrm{Ca}^{2+}$ and $\mathrm{H}^{+}$) composed $75 \%$ of the total mass of coarse particles at the Northeast crater (number of samples, $\mathrm{n}=6$ ), but only $15 \%$ of the total mass at Voragine/Bocca Nuova $(n=2)$. In fine particles the corresponding contributions of soluble material to the total mass were $57 \%$ (Northeast crater) and 38\% (Voragine/Bocca Nuova). The 
Table 1. Mean Mass and Soluble Ion Composition $\left(\mu \mathrm{g} \mathrm{m}^{-3}\right)$ of Coarse $(>3.5 \mu \mathrm{m}$ Diameter) and Fine $(<3.5 \mu \mathrm{m}$ Diameter $)$ Mt. Etna Summit Aerosols Measured During the Period 28 July to 5 August $2004^{\mathrm{a}}$

\begin{tabular}{llll}
\hline & Northeast Crater $(\mathrm{n}=6)$ & Voragine/Bocca Nuova $(\mathrm{n}=2)$ & Torre del Filosofo $(\mathrm{n}=1)$ \\
\hline Coarse fraction & & & 2804.77 \\
Total mass & 1459.70 & 22.59 & 1.03 \\
Fluoride & 49.28 & 0.66 & 0.20 \\
Chloride & 0.81 & 249.52 & 26.89 \\
Sulfate & 753.19 & 0.21 & 0.22 \\
Nitrate & 0.83 & 11.68 & 3.39 \\
Sodium & 101.06 & 3.81 & 13.55 \\
Ammonium & 2.13 & 5.79 & 4.80 \\
Potassium & 168.48 & 3.82 & 0.45 \\
Magnesium & 1.07 & 14.16 & 1.88 \\
Calcium & 10.10 & 1.56 & 0.00 \\
H & 4.40 & 302.51 & 52.42 \\
$\Sigma$ ions & 1091.33 & 0.15 & 0.19 \\
$\Sigma$ ions/total mass & 0.75 & & 150.06 \\
Fine fraction & & 4498.75 & 0.00 \\
Total mass & 169.26 & 1.02 & 0.00 \\
Fluoride & 2.61 & 0.35 & 48.99 \\
Chloride & 0.73 & 1629.94 & 0.08 \\
Sulfate & 66.50 & 0.14 & 0.12 \\
Nitrate & 0.13 & 7.58 & 3.51 \\
Sodium & 8.48 & 28.83 & 0.96 \\
Ammonium & 2.90 & 8.97 & 0.21 \\
Potassium & 12.31 & 0.31 & 0.58 \\
Magnesium & 0.19 & 0.55 & 0.11 \\
Calcium & 2.38 & 23.20 & 54.55 \\
$\mathrm{H}^{+}$ & 0.74 & 1700.91 & 0.36 \\
$\Sigma$ ions & 96.54 & 0.38 & \\
$\Sigma$ ions/total mass & 0.57 & & \\
\hline In & & & \\
\hline
\end{tabular}

${ }^{\mathrm{a}} \mathrm{n}=$ number of samples.

distinct nature of these emissions was also reflected in their relative contents of mineral cations and acidic (sulfate-rich) material, with large differences between (total) mass ratios $\mathrm{Ca}^{2+} / \mathrm{SO}_{4}^{2-}, \mathrm{K}^{+} / \mathrm{SO}_{4}^{2-}$ and $\mathrm{Na}^{+} / \mathrm{SO}_{4}^{2-}$ measured at Northeast crater $(1.5 \%, 22 \%$ and $13 \%$, respectively) and at Voragine/ Bocca Nuova $(0.8 \%, 0.8 \%$ and $1.0 \%$, respectively). In considering the mineral contents reported here it should be noted that the solubility of these species within highly acidic aerosols will be greater than their solubilities in water, and that mineral particles emitted from the magma or during wall collapses will undergo progressive dissolution within hygroscopic acidic aerosols during transport away from the vents. From the metal/sulfate ratios it is unlikely that the unaccounted aerosol mass at Voragine/Bocca Nuova could be due to the presence of unmeasured insoluble minerals, suggesting the existence of particulates containing higher water content. This is further supported by elevated acidity of the total (fine plus coarse) aerosol at Voragine/Bocca Nuova $\left(\mathrm{H}^{+}=24.8 \mu \mathrm{g} \mathrm{m}^{-3}, \mathrm{H}^{+} /\right.$total ions $\left.=1.2 \%\right)$ compared to Northeast crater $\left(\mathrm{H}^{+}=5.1 \mu \mathrm{g} \mathrm{m}^{-3}, \mathrm{H}^{+} /\right.$total ions $\left.=0.4 \%\right)$, because of the highly hygroscopic nature of sulfuric acidcontaining particles. At Northeast crater the lower overall acidity may be explained by partial neutralization associated with acid leaching of metal ions from mineral (ash) particles.

[9] Differences in the chemical signatures of the aerosols emitted from the various vents were accompanied by different measured size distributions (Figures 2 and 3a). While the size distributions at Bocca Nuova and Voragine were similar, with very high number concentrations of fine submicron particles, a different distribution was obtained at Northeast crater, with a greater contribution of larger particles in the size range $2-7 \mu \mathrm{m}$. Higher water content of the Northeast crater plume (which was observed to be more condensing) could increase particle growth due to condensation onto preexisting particles, while the higher coarse fraction concentrations of sodium and potassium evidence the presence of larger mineral-containing particles at Northeast crater, with a higher percentage of the particle mass being accounted for by dissolved material, notably sulfate, sodium and potassium.

[10] The mixed plume flowing down Etna's eastern flank, in the Valle del Bove, showed the combined influences of the summit sources, and aerosol number concentrations in all size bins were much higher than background. Within the mixed plume the aerosol size distribution showed a relative increase in number concentrations of intermediate sized particles $(<10 \mu \mathrm{m}) 6 \mathrm{~km}$ downwind (Figure $3 \mathrm{~b}$ ), compared to distributions obtained for both the upper eastern flank plume and lower-tropospheric background air (sampled upwind at the same altitude as the downwind plume measurements), presumably because of higher removal rates of the finest (by coagulation) and coarsest (by deposition) particles [Jaenicke, 1998]. This did not appear to be due to hygroscopic effects since particle growth (of summit aerosols) was not observed at the relative humidity measured downwind ( $\mathrm{RH}<50 \%$ ) (Figure 3c), although growth of volcanic aerosols was observed at higher humidity (Figure 3d). Particle growth would therefore be expected following transport into more humid conditions, such as over the ocean or following changes in the prevailing meteorology.

[11] Summit aerosol mass concentrations in the size fractions most commonly used for air quality monitoring and human health effects purposes, $\mathrm{PM}_{2.5}$ (particles with aerodynamic diameter less than $2.5 \mu \mathrm{m}$ ) and $\mathrm{PM}_{10}$ (aero- 


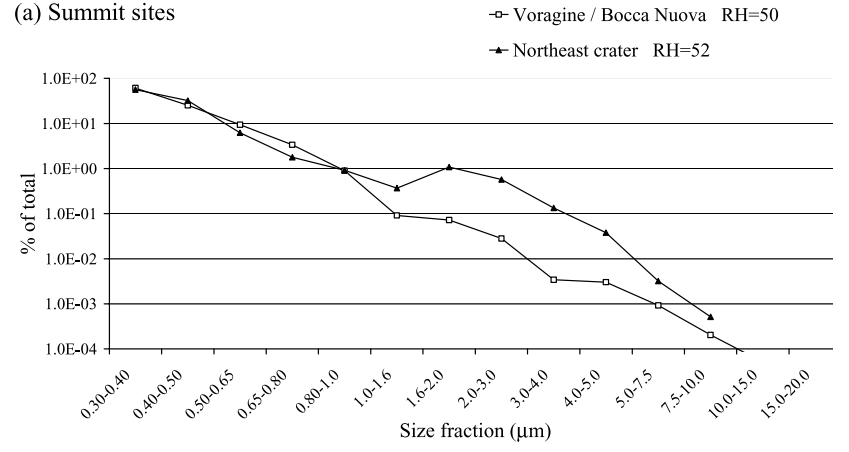

(c) Voragine / Bocca Nuova

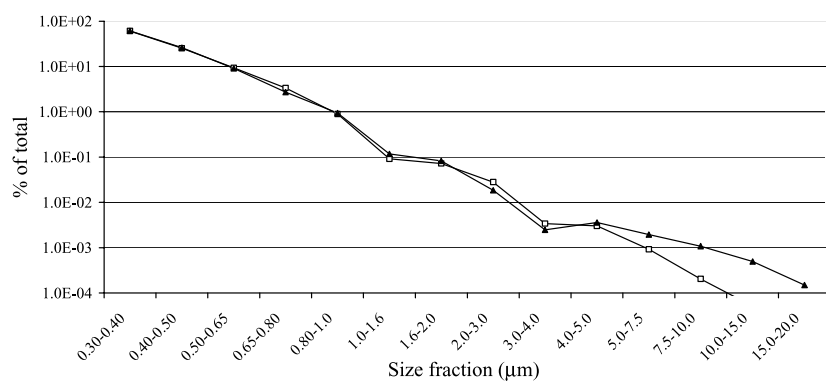

(b) Mixed plume

- Upper flank

$\rightarrow 6 \mathrm{~km}$ downwind

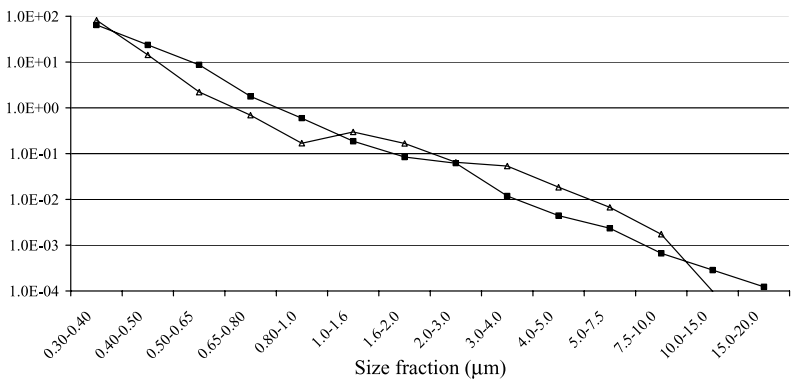

(d) Northeast crater

$-\mathrm{RH}=87$
$-\mathrm{RH}=52$

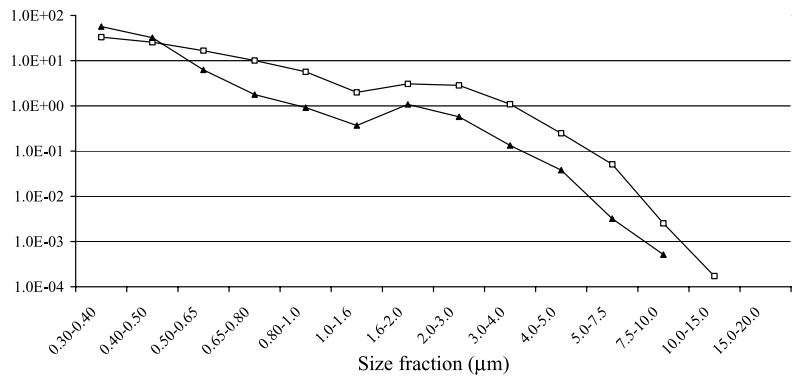

Figure 3. (a) Size distributions of Voragine/Bocca Nuova and Northeast crater aerosols at relative humidities of $50 \%(n=5)$ and $52 \%(n=5)$, respectively. (b) Size distributions of aerosols in the mixed plume on the upper flank and $6 \mathrm{~km}$ downwind. (c) Size distributions of Voragine/Bocca Nuova aerosols at relative humidities of $27 \%(\mathrm{n}=8)$ and $50 \%(\mathrm{n}=5)$. (d) Size distributions of Northeast crater aerosols at relative humidities of $52 \%(n=5)$ and $87 \%(n=10)$. Concentrations in each size bin are expressed as a percentage of the total number concentration.

dynamic diameter less than $10 \mu \mathrm{m}$ ) were computed from the measured size-segregated aerosol number concentrations and particle densities calculated from the chemical composition. Average particle densities were $2040 \mathrm{~kg} \mathrm{~m}^{-3}$ at Northeast crater, and $1310 \mathrm{~kg} \mathrm{~m}^{-3}$ at Voragine and Bocca Nuova. Large temporal variability of aerosol mass concentration was observed because of both changing position of the aerosol spectrometer (deployed on foot around the craters) and natural fluctuations in plume direction. Mean and maximum mass concentrations (Table 2) are in quantitative agreement with those obtained from the filter gravimetric measurements.

\subsection{Relationship Between $\mathrm{SO}_{2}$ Column Amount and Particle Number Concentration During Downwind Transport and Fumigation}

[12] Measurements of particle number concentrations $\left(\mathrm{PM}_{0.3-0.4}\right)$ and $\mathrm{SO}_{2}$ column during the four downwind traverses (T1-T4) through Etna's plume were analyzed to identify the principal aerosol sources, whether volcanic, urban or vehicular. Additional to the volcano, outside of towns road vehicles were the only other noted local source of particles. Figure $4 \mathrm{a}$ presents all of the $\mathrm{PM}_{0.3-0.4}$ data obtained during the four traverses under the plume (as well as the $\mathrm{PM}_{0.3-0.4}$ data which continued to be collected between periods of plume detection while following the route shown in Figure 1) together with the $\mathrm{SO}_{2}$ column measurements (which were only collected during traverses under the plume, not continuously). The measurements obtained under clean rural conditions, in towns or in the presence of vehicles are illustrated using separate symbols. Strong vehicle presence in towns is illustrated where this source was considered likely to exceed the urban background (for example when static at filling stations, in congested traffic, or behind a diesel truck). The unfiltered $\mathrm{SO}_{2}$ column data show the negative spikes obtained because of passage below overhanging trees. Under Etna's plume the volcanic contribution to the $\mathrm{SO}_{2}$ column far exceeded the anthropogenic $\mathrm{SO}_{2}$ component. This is readily seen by simple calculation, for example given a hypothetical (ex-

Table 2. Mean and Maximum (in Italics) $\mathrm{PM}_{2.5}$ and $\mathrm{PM}_{10}$ Concentrations $\left(\mu \mathrm{g} \mathrm{m}^{-3}\right)$ at Summit Sites, Computed From 1 Min Average Aerosol Number Concentrations, and for Average Particle Densities of $2040 \mathrm{~kg} \mathrm{~m}^{-3}$ (Northeast Crater), and $1310 \mathrm{~kg} \mathrm{~m}^{-3}$ (Voragine and Bocca Nuova)

\begin{tabular}{lclc}
\hline & $\begin{array}{c}\text { Northeast Crater } \\
(\mathrm{n}=71)\end{array}$ & $\begin{array}{c}\text { Voragine } \\
(\mathrm{n}=31)\end{array}$ & $\begin{array}{c}\text { Bocca Nuova } \\
(\mathrm{n}=10)\end{array}$ \\
\hline $\mathrm{PM}_{10}$ & $898(8413)$ & $240(896)$ & $629(1073)$ \\
$\mathrm{PM}_{2.5}$ & $445(2514)$ & $99(326)$ & $389(706)$ \\
\hline
\end{tabular}



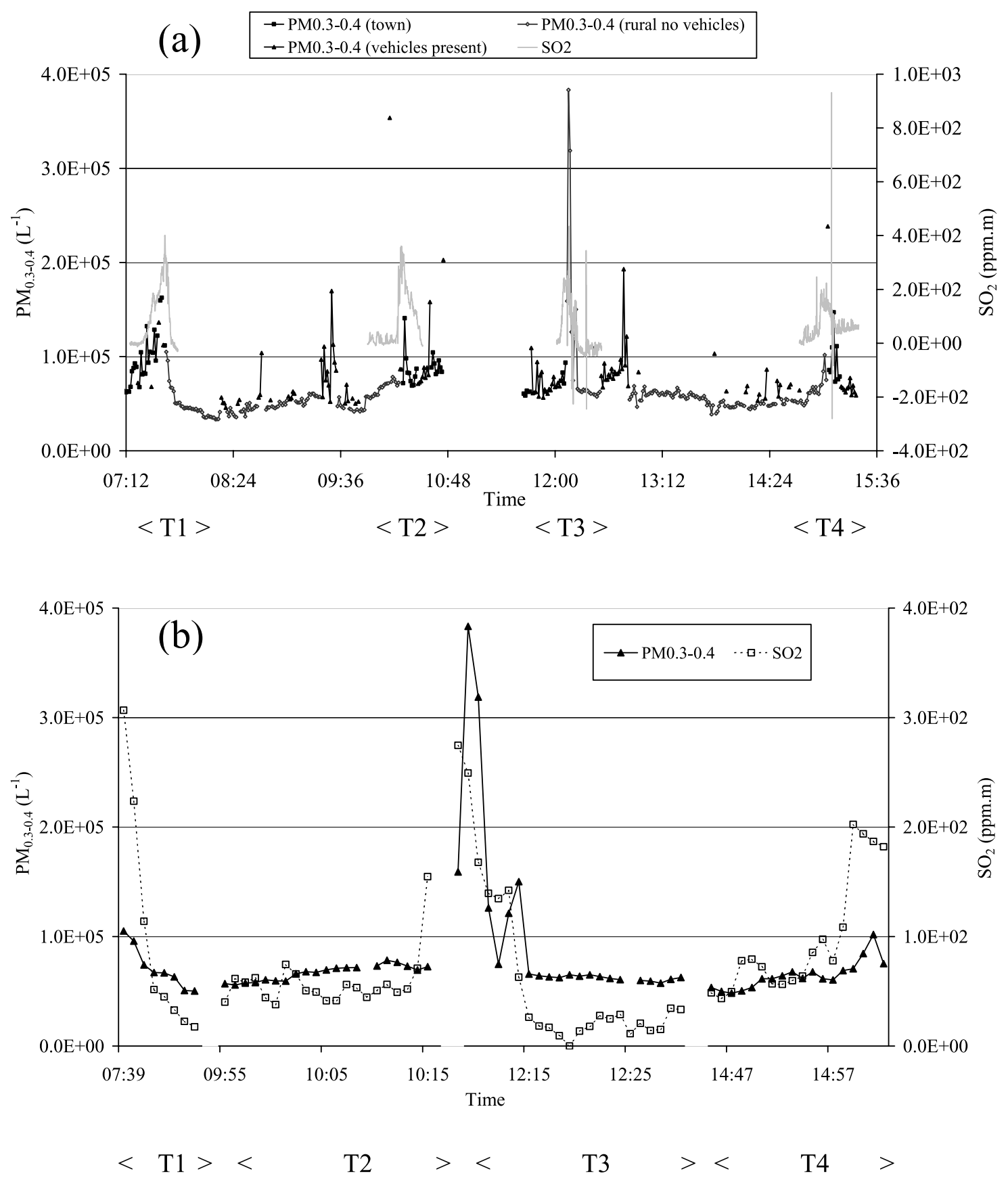

Figure 4. (a) $\mathrm{PM}_{0.3-0.4}$ and $\mathrm{SO}_{2}$ concentrations during downwind traverses (T1-T4) through Etna's plume on 4 August 2004 (all data). (b) $\mathrm{PM}_{0.3-0.4}$ and $\mathrm{SO}_{2}$ concentrations during downwind traverses (T1-T4) through Etna's plume on 4 August 2004 (filtered to exclude anthropogenic sources).

tremely high) urban roadside $\mathrm{SO}_{2}$ concentration of $50 \mathrm{ppb}$ extending vertically for $10 \mathrm{~m}$ the contribution to the total $\mathrm{SO}_{2}$ column would be $0.5 \mathrm{ppm} . \mathrm{m}$, while under the volcanic plume column amounts frequently exceeded 100 ppm.m. The plume width during traverses, at a distance of around $10 \mathrm{~km}$ from the summit craters, was estimated at $5-10 \mathrm{~km}$ on the basis of the DOAS measurements, vehicle speed and distance covered. $\mathrm{SO}_{2}$ fluxes from the volcano were calculated considering a wind speed of $5.5 \mathrm{~m} \mathrm{~s}^{-1}$ at $3300 \mathrm{~m}$ a.s.l. (measured by balloon sondes launched from Trápani in western Sicily: http://weather.uwyo.edu/upperair/ sounding.html). Mean net $\mathrm{SO}_{2}$ flux, with standard deviation based on changing $\mathrm{SO}_{2}$ column over the four traverses, was $1380 \pm 270 \mathrm{Mg} \mathrm{d}^{-1}$.

[13] At the time of the measurements Etna's plume was advecting toward the southeast and the towns of Zafferana and Milo, so that in these built up areas a mixture of aerosols from multiple sources was expected. In order to confirm the presence of the volcanic plume on the ground our approach was to examine the covariance between 
particle number concentrations and $\mathrm{SO}_{2}$ column, necessitating the prior removal of any data points acquired within the urban areas or in the presence of vehicles (as shown in Figure 4a). During the first traverse, from south to north along Etna's southeastern flank, the volcanic plume (evidenced from the $\mathrm{SO}_{2}$ column data) was detected in Zafferana and Milo, and continued into the unpopulated region north of Milo (Figure 1). The second traverse was conducted in the opposite direction, heading south toward and then through Milo and Zafferana. The plume was first detected (with small fluctuating increases in the $\mathrm{SO}_{2}$ signal) in the rural area north of Milo, with the main $\mathrm{SO}_{2}$ signal obtained just prior to entering Milo. Peak $\mathrm{SO}_{2}$ column was observed between Milo and Zafferana, with return to baseline shortly before exiting Zafferana. During the third traverse (northward) the plume was again detected approaching Milo, with peak $\mathrm{SO}_{2}$ column obtained in the rural area north of the town, coincident with peak aerosol number concentration. Aerosol measurements were then continued (in the absence of plume) while ascending the flank of the volcano to the Pizzi de Neri observatory, and subsequently returning toward Milo. $\mathrm{SO}_{2}$ column measurements (fourth traverse) detected the plume near the same point as previously, several minutes before entering Milo, with midplume obtained at the northern perimeter of Milo.

[14] For the purpose of identifying the presence on the ground of the volcanic plume, data were excluded where these were collected in built-up areas, while the instrumented vehicle was stationary, or downwind of other road vehicles. Figure $4 \mathrm{~b}$ shows the simultaneous $\mathrm{PM}_{0.3-0.4}$ and $\mathrm{SO}_{2}$ column data for the periods not affected by anthropogenic emissions. Here the DOAS data were averaged over the same 1 min periods as the particle data (since DOAS retrievals were made every $2.5 \mathrm{~s}$ ), and spikes in the DOAS signal due to passage under trees were removed. Temporal offsets might be expected between the $\mathrm{SO}_{2}$ column and aerosol data because of the different natures of the two techniques, since the UV spectroscopy determines the vertical atmospheric column amount of $\mathrm{SO}_{2}$, while the aerosol measurement monitors discrete air parcels at ground level. Nevertheless, the values of the Pearson correlation coefficient $(\mathrm{R})$ obtained between $\mathrm{PM}_{0.3-0.4}$ and $\mathrm{SO}_{2}$ column during individual traverses are 0.97 (T1), 0.78 (T3) and 0.79 (T4). These correlations are significant at the 0.005 level of significance. The value of $\mathrm{R}$ for $\mathrm{T} 2$ was 0.13 . For this traverse there was no significant correlation because most data points obtained under the plume were excluded using our quality control procedure (since the plume peak occurred in an urban area). These results support the notion that Etna's plume was grounding in the vicinity of Zafferana and Milo, because of turbulent transport from higher altitudes. Particle sedimentation could not account for the observed vertical transport. During horizontal transport at $5 \mathrm{~m} \mathrm{~s}^{-1}$ over a distance of $10 \mathrm{~km}$ (giving a travel time of $2000 \mathrm{~s}$ ), a $10 \mu \mathrm{m}$ diameter particle, possessing a sedimentation velocity of ca. $3 \mathrm{~mm} \mathrm{~s}^{-1}$ [Mark, 1998], will have descended only $6 \mathrm{~m}$ because of sedimentation, while similar calculation shows that a $1 \mu \mathrm{m}$ particle (sedimentation velocity of ca. $0.003 \mathrm{~mm} \mathrm{~s}^{-1}$ ) will have descended just $6 \mathrm{~mm}$. For particles smaller than $1 \mu \mathrm{m}$ sedimentation velocities are extremely small.
[15] Peak $\mathrm{PM}_{2.5}$ and $\mathrm{PM}_{10}$ mass concentrations in the plume sector (including urban areas) were determined from the measured number size distribution and for a particle density of $1260 \mathrm{~kg} \mathrm{~m}^{-3}$ calculated in accordance with the chemical composition of particles collected in the mixed plume at the Torre del Filosofo car park (Figure 1 and Table 1). The Torre del Filosofo site is a convenient location for collection of material within the mixed plume originating from the summit craters, after a transport time on the order of minutes. Mass concentrations in the downslope fumigated zone were 2-3 times higher than outside the plume at similar altitude, with $\mathrm{PM}_{2.5}$ maxima of $10.8 \mu \mathrm{g} \mathrm{m}^{-3}, 8.3 \mu \mathrm{g} \mathrm{m}^{-3}, 11.9 \mu \mathrm{g} \mathrm{m}^{-3}$ and $6.4 \mu \mathrm{g} \mathrm{m}^{-3}$, and $\mathrm{PM}_{10}$ maxima of $25.1 \mu \mathrm{g} \mathrm{m}^{-3}, 16.9 \mu \mathrm{g} \mathrm{m}^{-3}, 41.5 \mu \mathrm{g} \mathrm{m}^{-3}$ and $13.0 \mu \mathrm{g} \mathrm{m}^{-3}$ during traverses $1-4$, respectively. The significance of the volcanic source is illustrated, since highest values of both $\mathrm{PM}_{2.5}$ and $\mathrm{PM}_{10}$ were obtained during $\mathrm{T} 3$, in a rural area unaffected by any urban aerosol emissions.

[16] At these downwind sites the strongest correlations between volcanogenic $\mathrm{SO}_{2}$ column and particle number concentration were for the $\mathrm{PM}_{0.4-0.5}$ and $\mathrm{PM}_{0.5-0.65}$ size fractions (correlation coefficients, $\mathrm{R}=0.71$ and 0.70 , respectively, $n=69$, significant at 0.005 level) (Figure 5). An increase in the value of $\mathrm{R}$ within the size range $2.0-$ $7.5 \mu \mathrm{m}$, with a secondary maximum for the 3.0-4.0 $\mu \mathrm{m}$ fraction, illustrates the multimodal nature of the downwind volcanic aerosol size distribution (as is also shown by the T3 and summit aerosol size distributions in Figure 2). These results support earlier assertions that volcanic particle size distributions during quiescent degassing tend to show several size modes [e.g., Mather et al., 2003, 2004; Watson and Oppenheimer, 2000, 2001], usually interpreted as due to the coexistence of a sulfate-rich smaller phase and a larger phase composed of water droplets or small spheres of glass originating from bubble bursting on the magma surface.

\subsection{Applications and Human Health Issues}

[17] The results show that ground-level measurements of volcanic aerosol size distributions can distinguish between individual plumes emitted from the same volcano, providing that the plumes are well separated, and should therefore also be able to identify changes in the nature of aerosol emissions arising, for example, from altered activity state or magma level in the conduit (which could influence the aerosol properties because of time available for gas-particle or gas-wall rock interactions). These findings appear consistent with earlier work at Etna [Watson and Oppenheimer, 2000, 2001] in which a Sun photometer identified ventspecific differences in aerosol size distributions.

[18] It is clear that the diffuse bottom edge of Etna's plume was grounding along the flanks of the volcano during this period of observation and measurement. This was due to turbulent downward mixing since rates of both gravitational settling and diffusion for these particles are far too slow to contribute to the observed rapid vertical transport [Mark, 1998; Zhang et al., 2001]. Although grounding may particularly be enhanced in the vicinity of the Valle del Bove because of rapid altitude change and the associated rotor effect and turbulence downwind of a large mountain [Doyle and Durran, 2002], the measurements across the southeast flank confirmed that it was not confined to the 


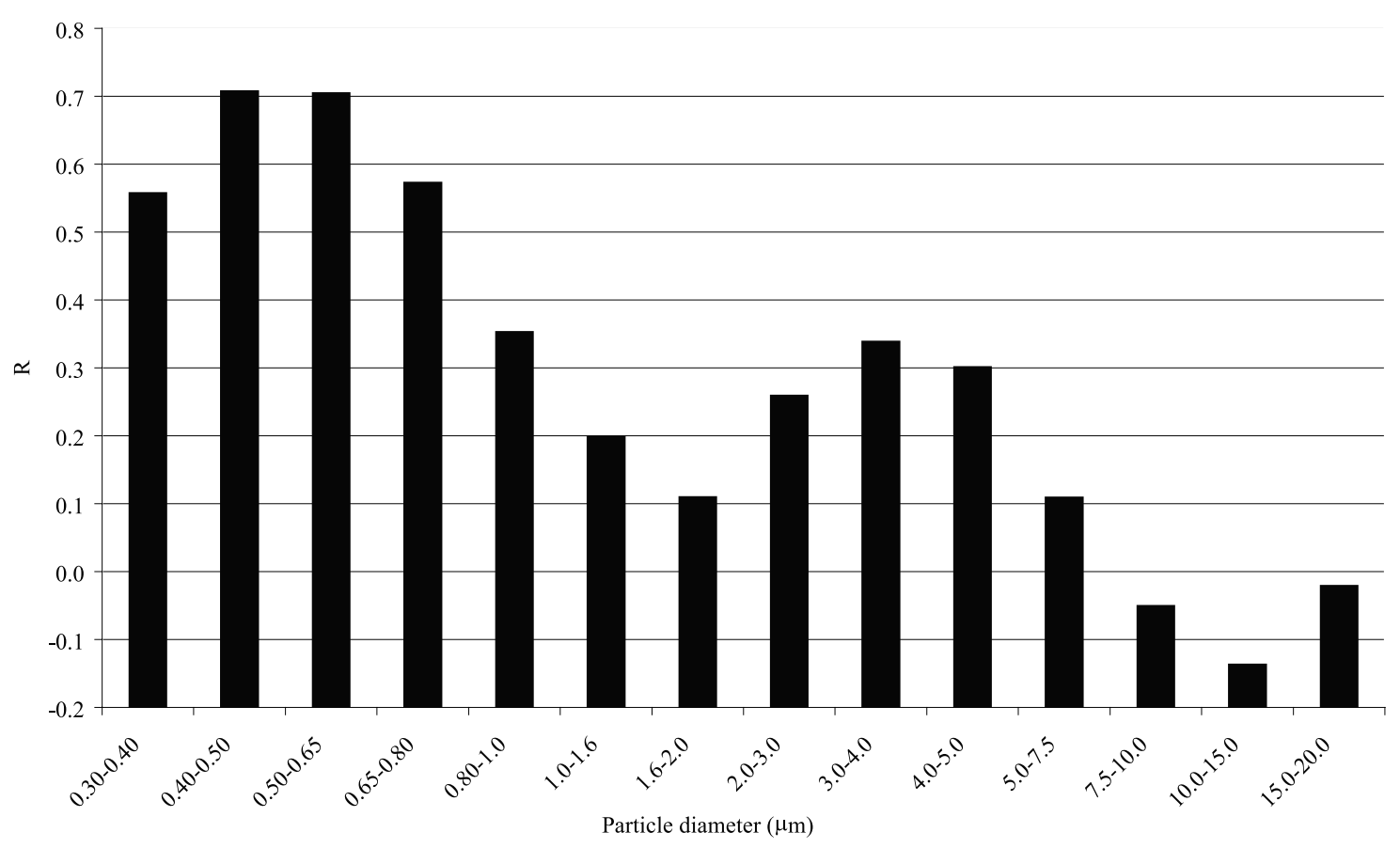

Figure 5. Correlation coefficient $(\mathrm{R}), \mathrm{SO}_{2}$ column versus particle number concentration during traverses, according to particle size fraction $(\mathrm{n}=69)$.

Valle del Bove. In the past, the potential deposition of volcanogenic gases and aerosols on Etna's upper eastern flank has been suggested on a biogeochemical basis [Notcutt and Davies, 1989; Monna et al., 1999]; our results provide the first direct evidence of the presence of volcanic aerosols at ground level, showing that in addition to washout/rainout of lofting plumes, dry deposition of volcanic aerosols, as well as of gases as previously reported [Aiuppa et al., 2004], will increase inputs to terrestrial surfaces and ecosystems.

[19] The presence of elevated atmospheric aerosol mass concentrations has been widely linked to adverse effects on human health [e.g., Pope et al., 1992; Dockery et al., 1993; Schwartz et al., 1996]. However, only recently have studies begun to consider the metabolic significance of different physical and chemical components of the aerosol. Volcanic dusts may contain elevated levels of crystalline silica, some forms of which are considered carcinogenic or may induce silicosis [Horwell et al., 2003a, and references therein]. Volcanic particles are often highly acidic [Allen et al., 2002b], and contain elevated levels of toxic trace metals [Allen et al., 2000]. Particles rich in iron can, once inhaled, generate high concentrations of free radicals in lung tissues [Horwell et al., 2003b]. These properties might be compounded by the chemical modifications which could occur once a volcanic plume mixes with anthropogenically polluted air masses, such as during plume transport into urban areas possessing numerous sources of hydrocarbons (from road transport, industrial or domestic emissions). The abundance of volcanogenic halogens, and formation of free halogen radicals in the presence of other atmospheric oxidants such as $\mathrm{OH}$, could transform organic compounds into more toxic halogenated forms [Gullett et al., 2000; Smirnov et al., 1993], however no studies of this in the volcanic context have yet been attempted. Further investigation into the composition and crystalline content of volcanic dusts at Etna and elsewhere, and the effects of fine acidic aerosol on human health in general, are needed. At the time of these measurements, undertaken during quiescent degassing, airborne particulate mass concentrations were very high at Etna's summit and likely to pose a threat to the health of visitors if they were downwind of the summit craters and within the volcanic plume. At flank locations $10 \mathrm{~km}$ downwind concentrations were elevated, relative to background, in sectors fumigated by the plume, but were unlikely to exceed the current European statutory limit for airborne particulates, introduced on 1 January 2005 , of $50 \mathrm{\mu g} \mathrm{m}^{-3}$ as a 24-hour mean for $\mathrm{PM}_{10}$ (not be exceeded on more than 35 days per year). Further longerterm monitoring studies would be necessary to confirm such compliance.

\section{Conclusions}

[20] Measured differences in the size distributions of directly sampled aerosols from individual vents on Mount Etna are consistent with their different chemistries, and in agreement with the remote sensing observations of Watson and Oppenheimer [2001]. The Northeast crater plume was distinct from that of Bocca Nuova or Voragine, with the presence of denser, higher mineral content aerosols attributed to either Strombolian or gas puffing activity at the magma surface in the vent. In the absence of significant anthropogenic sources, ground level measurement of aerosol number size distributions could potentially be used to detect the presence of volcanogenic emissions downwind, however our data show that this might be difficult in urban areas or in the vicinity of road transport systems (unless the 
volcanic source was comparatively large). The portable aerosol spectrometer provides a useful additional technique for characterization of volcanic emissions on the ground. For example, it could readily be deployed alongside continuous electrochemical sensors measuring gases such as $\mathrm{H}_{2} \mathrm{O}, \mathrm{CO}_{2}$ and $\mathrm{SO}_{2}$ [Shinohara, 2005]. A further advantage lies in its suitability for nighttime use, in ashy plumes or under cloudy conditions, so that (like electrochemical sensors) it is complementary to optical techniques requiring external light sources.

[21] Downwind aerosol measurements showed mixing of Etna's plume to ground level, with number concentrations of all particle size fractions in the fumigated sector being elevated above background. Under conditions of peak aerosol number concentration within the plume, increase in the size fraction between $2.0 \mu \mathrm{m}$ and $7.5 \mu \mathrm{m}$ was attributed to the volcanic source. It is concluded that aerosols within the plume from Mount Etna are likely to ground on the southeastern flanks of the volcano, at times fumigating towns and other inhabited areas. This may have a detrimental effect on the health of the local population, suggesting a need for further work to improve understanding of the interactions between volcanic plumes and urban air.

[22] Acknowledgments. The authors thank Jianxin Yin, Ken Sims and Manuela Bagnato for help during fieldwork and sample analysis. T.M. acknowledges the UK Natural Environment Research Council (NERC), the Aerosol Society, the Royal Society, Shell and the Cambridge Philosophical Society for financial support. A.M. acknowledges NERC for provision of a research fellowship. C.O. and P.D. gratefully acknowledge research support from the Gruppo Nazionale per la Vulcanologia (project "Development of an integrated spectroscopic system for remote and continuous monitoring of volcanic gas"). P.D. is indebted to T. Hosay (ISSeP) for loan of an aerosol spectrometer and technical advice.

\section{References}

Aiuppa, A., C. Federico, A. Paonita, G. Pecoraino, and M. Valenza (2002), $\mathrm{S}, \mathrm{Cl}$ and $\mathrm{F}$ degassing as an indicator of volcanic dynamics: The 2001 eruption of Mount Etna, Geophys. Res. Lett., 29(11), 1559, doi:10.1029/ 2002 GL015032.

Aiuppa, A., S. Bellomo, W. D’Alessandro, C. Federico, M. Ferm, and M. Valenza (2004), Volcanic plume monitoring at Mount Etna by diffusive (passive) sampling, J. Geophys. Res., 109, D21308, doi:10.1029/ 2003JD004481.

Allard, P. (1997), Endogenous magma degassing and storage at Mount Etna, Geophys. Res. Lett., 24, 2219-2222.

Allard, P., M. Burton, and F. Mure (2005), Spectroscopic evidence for a lava fountain driven by previously accumulated magmatic gas, Nature, 433, 407-410.

Allen, A. G., P. J. Baxter, and C. J. Ottley (2000), Gas and particle emissions from Soufrière Hills volcano, Montserrat, W.I.: Characterization and health hazard assessment, Bull. Volcanol., 62(1), 6-17.

Allen, A. G., B. M. Davison, J. D. James, L. Robertson, R. M. Harrison, and C. N. Hewitt (2002a), Influence of transport over a mountain ridge on the chemical composition of marine aerosols during the ACE-2 Hillcloud experiment, J. Atmos. Chem., 41, 83-107.

Allen, A. G., C. Oppenheimer, M. Ferm, P. J. Baxter, L. A. Horrocks, B. Galle, A. J. S. McGonigle, and H. J. Duffell (2002b), Primary sulphate aerosol and associated emissions from Masaya volcano, Nicaragua, J. Geophys. Res., 107(D23), 4682, doi:10.1029/2002JD002120.

Allen, A. G., A. A. Cardoso, and G. O. da Rocha (2004), Influence of sugar cane burning on aerosol soluble ion composition in southeastern Brazil, Atmos. Environ., 38, 5025-5038.

Andronico, D. (2005), Rapporto settimanale sull'attività eruttiva dell'Etna (7-13 marzo 2005), INGV Rep. UFVG2005/35, Ist. Naz. di Geofis. e Vulcanol., Catania, Italy.

Andronico, D., M. Coltelli, A. Cristaldi, P. del Carlo, and S. Scollo (2003), The 2002-2003 Etna explosive activity: Tephra dispersal and its effects, paper presented at General Assembly, Ital. Natl. Volcanol. Group, Rome, 9-11 June.
Andronico, D., et al. (2005), A multi-disciplinary study of the 2002-03 Etna eruption: Insights into a complex plumbing system, Bull. Volcanol., 67, 314-330.

Behncke, B., and M. Neri (2003), The July-August 2001 eruption of Mt Etna (Sicily), Bull. Volcanol., 65, 461-476.

Bluth, G. J. S., C. C. Schnetzler, A. J. Krueger, and L. S. Walter (1993), The contribution of explosive volcanism to global atmospheric sulphur dioxide concentrations, Nature, 366, 327-329.

Bonaccorso, A., S. Calvari, M. Coltelli, C. Del Negro, and S. Falsaperla (Eds.) (2004), Mt. Etna: Volcano Laboratory, Geophys. Monogr. Ser., vol. 143, AGU, Washington, D. C.

Burton, M. R., et al. (2005), Etna 2004-2005: An archetype for geodynamically-controlled effusive eruptions, Geophys. Res. Lett., 32, L09303, doi:10.1029/2005GL022527.

Caltabiano, T., M. Burton, S. Giammanco, P. Allard, N. Bruno, F. Muré, and R. Romano (2004), Volcanic gas emissions from the summit craters and flanks of Mt. Etna, 1987-2000, in Mt. Etna: Volcano Laboratory, Geophys. Monogr. Ser, vol. 143, edited by A. Bonaccorso et al., pp. 111128, AGU, Washington, D. C.

Carn, S. A., A. J. Krueger, G. J. S. Bluth, S. J. Schaefer, N. A. Krotkov, I. M. Watson, and S. Datta (2003), Volcanic eruption detection by the Total Ozone Mapping Spectrometer (TOMS) instruments: A 22-year record of sulphur dioxide and ash emissions, in Volcanic Degassing, edited by C. Oppenheimer, D. M. Pyle, and J. Barclay, Geol. Soc. Spec. Publ., 213, 177-202.

Chester, D. K., A. M. Duncan, J. E. Guest, and C. R. J. Kilburn (1985), Mount Etna: The Anatomy of a Volcano, CRC Press, Boca Raton, Fla.

Dockery, C. W., D. A. Pope, X. Xu, J. D. Spengler, J. H. Ware, M. A. Fay, B. G. Ferris, and F. D. Speizer (1993), An association between air pollution and mortality in six US cities, N. Engl. J. Med., 329, 1753-1759.

Doyle, J. D., and D. R. Durran (2002), The dynamics of mountain-waveinduced rotors, J. Atmos. Sci., 59, 186-201.

Francis, P., M. R. Burton, and C. Oppenheimer (1998), Remote measurements of volcanic gas compositions by solar occultation spectroscopy, Nature, 396, 567-570.

Galle, B., C. Oppenheimer, A. Geyer, A. J. S. McGonigle, M. Edmonds, and L. A. Horrocks (2003), A miniaturised UV spectrometer for remote sensing of $\mathrm{SO}_{2}$ fluxes: A new tool for volcano surveillance, J. Volcanol. Geotherm. Res., 119, 241-254.

Gullett, B. K., A. F. Sarofim, K. A. Smith, and C. Procaccini (2000), The role of chlorine in dioxin formation, Process Safety Environ. Prot., 78(B1), 47-52.

Horrocks, L., M. Burton, P. Francis, and C. Oppenheimer (1999), Stable gas plume composition measured by OP-FTIR spectroscopy at Masaya Volcano, Nicaragua, 1998-1999, Geophys. Res. Lett., 26(23), 3497-3500.

Horwell, C. J., R. S. J. Sparks, T. S. Brewer, E. W. Llewellin, and B. J. Williamson (2003a), Characterization of respirable volcanic ash from the Soufrière Hills volcano, Montserrat, with implications for human health hazards, Bull. Volcanol., 65, 346-362.

Horwell, C. J., I. Fenoglio, K. V. Ragnarsdottir, R. S. J. Sparks, and B. Fubini (2003b), Surface reactivity of volcanic ash from the eruption of Soufrière Hills volcano, Montserrat, with implications for health hazards, Environ. Res., 93, 202-215.

Jaenicke, R. (1998), Atmospheric aerosol size distribution, in Atmospheric Particles, edited by R. M. Harrison and R. E. van Grieken, pp. 1-28, John Wiley, Hoboken, N. J.

Love, S. P., F. Goff, D. Counce, C. Siebe, and H. Delgado (1998), Passive infrared spectroscopy of the eruption plume at Popocatépetl volcano, Mexico, Nature, 396, 563-566.

Mark, D. (1998), Atmospheric aerosol sampling, in Atmospheric Particles, edited by R. M. Harrison and R. E. van Grieken, pp. 29-94, John Wiley, Hoboken, N. J.

Mather, T. A., A. G. Allen, C. Oppenheimer, D. M. Pyle, and A. J. S McGonigle (2003), Size-resolved characterisation of soluble ions in the particles in the tropospheric plume of Masaya volcano, Nicaragua: Origins and plume processing, J. Atmos. Chem., 46(3), 207-237.

Mather, T. A., V. I. Tsanev, D. M. Pyle, A. J. S. McGonigle, C. Oppenheimer, and A. G. Allen (2004), Characterization and evolution of tropospheric plumes from Lascar and Villarrica volcanoes, Chile, J. Geophys. Res., 109, D21303, doi:10.1029/2004JD004934.

Monna, F., A. Aiuppa, G. Dongarrà, and D. Varrica (1999), Pb isotope composition in lichens and aerosols from Eastern Sicily: Insights into the regional impact of volcanoes on the environment, Environ. Sci. Technol., 33, 2517-2523.

Mori, T., K. Notsu, Y. Tohjima, and H. Wakita (1993), Remote detection of $\mathrm{HCl}$ and $\mathrm{SO}_{2}$ in volcanic gas from Unzen volcano, Japan, Geophys. Res. Lett., 20, 1355-1358.

Notcutt, G., and F. Davies (1989), Accumulation of volcanogenic fluoride by vegetation: Mt. Etna, Sicily, J. Volcanol. Geotherm. Res., 39, 329333. 
Oppenheimer, C., D. M. Pyle, and J. Barclay (2003), Volcanic Degassing, Geol. Soc. Spec. Publ., 213, 432 pp.

Platt, U. (1999), Modern methods of the measurement of atmospheric trace gases, Phys. Chem. Chem. Phys., 1, 5409-5415.

Pope, C. A., III, J. Schwartz, and M. Ransom (1992), Daily mortality and PM10 pollution in Utah Valley, Arch. Environ. Health, 42, 211-217.

Schwartz, J., D. W. Dockery, and L. M. Neas (1996), Is daily mortality associated specifically with fine particles?, J. Air Waste Manage. Assoc., 46, 927-939.

Shinohara, H. (2005), A new technique to estimate volcanic gas composition: Plume measurements with a portable multi-sensor system, J. Volcanol. Geotherm. Res., 143, 319-333.

Smirnov, V. V., T. N. Rostovshchikova, I. G. Tarkhanova, I. N. Novikov, V. B. Barabash, and I. A. Nasyr (1993), Reactions in liquid hydrogen chloride. 1. Chlorination of aromatic hydrocarbons, Kinet. Catalysis, 34(2), 204-206.

Stoiber, R. E., L. L. Malinconico Jr., and S. N. Williams (1983), Use of the correlation spectrometer at volcanoes, in Forecasting Volcanic Events, edited by H. Tazieff and J. C. Sabroux, pp. 425-444, Elsevier, New York.

Tanguy, J. C., M. Condomines, and G. Kieffer (1997), Evolution of the Mount Etna magma: Constraints on the present feeding system and eruptive mechanism, J. Volcanol. Geotherm. Res., 75, 221-250.

Watson, I. M., and C. Oppenheimer (2000), Particle size distributions of Mount Etna's aerosol plume constrained by Sun photometry, J. Geophys. Res., 105(D8), 9823-9829.

Watson, I. M., and C. Oppenheimer (2001), Photometric observations of Mt. Etna's different aerosol plumes, Atmos. Environ., 35(21), 3561 3572 .
Yin, J., A. G. Allen, R. M. Harrison, S. G. Jennings, E. Wright, M. Fitzpatrick, T. Healy, E. Barry, D. Ceburnis, and D. McCusker (2005), Major component composition of urban $\mathrm{PM}_{10}$ and $\mathrm{PM}_{2.5}$ in Ireland, Atmos. Res., 78, 149-165.

Zhang, L., S. Gong, J. Padro, and L. Barrie (2001), A size-segregated particle dry deposition scheme for an atmospheric aerosol module, Atmos. Environ., 35, 549-560.

A. Aiuppa, Dipartimento di Chimica e Fisica della Terra ed Applicazioni, University of Palermo, I-90123 Palermo, Italy.

A. G. Allen, School of Geography, Earth and Environmental Sciences, University of Birmingham, Birmingham B15 2TT, UK. (a.g.allen bham.ac.uk)

N. Bobrowski, Institute of Environmental Physics, University of Heidelberg, D-69120 Heidelberg, Germany.

B. Davison, Institute of Environmental and Natural Sciences, University of Lancaster, Lancaster LA1 4YW, UK.

P. Delmelle, Environmental Health Unit, Institut Scientifique de Service Public, 200 Rue du Chéra, B-4000 Liège, Belgium.

S. Inguaggiato, Istituto Nazionale di Geofisica e Vulcanologia, V. Ugo La Malfa, 153, I-90146 Palermo, Italy

T. A. Mather and D. M. Pyle, Department of Earth Sciences, University of Cambridge, Downing Street, Cambridge CB2 3EQ, UK.

A. J. S. McGonigle, Department of Geography, University of Sheffield, Winter Street, Sheffield S10 2TN, UK.

C. Oppenheimer, Department of Geography, University of Cambridge, Downing Place, Cambridge CB2 3EN, UK. 